\title{
DIAGNOSTICS OF PROMISING LABOR MARKETS FOR HIGH-TECH AND INNOVATIVE SECTORS OF THE REGIONAL ECONOMY
}

\author{
Assoc. Prof. DSc. Irina Filimonenko, \\ Prof. DSc. Dr. Zoya Vasilyeva, \\ Senior lecturer Olga Karpycheva, \\ Senior lecturer Oksana Ryzhkova,
}

Siberian Federal University, Russia

\begin{abstract}
The purpose of the study is to develop methodological bases for diagnosing promising labor markets to forecast the staffing needs for the high-tech and innovative sectors of the regional economy. The complexity of the task is in the need to identify intellectual and human resources for promising commodity and labor markets, which currently do not have business customers. Existing methods for assessing the staffing needs cannot fully consider the changes in the strategic priorities for the regional development. As a result, the forecast effectiveness and quality for staffing needs have been reduced. Consequently, despite the high demand in labor resources, territorial, sectoral and professional-skill imbalances in supply and demand exist, thus making barriers to building the intellectual potential of the region.
\end{abstract}

The authors identified the principles and patterns of changing business needs and professional competencies, relative to the changes in priorities of socio-economic, technological and innovative development of the region.

The article suggests using the technique of diagnostics to identify the differences in the parameters and components of the demand in labor resources in the promising markets based on quantitative parameters for the regional development, and modeling the redistribution of labor resources of the region between sectors of the economy, in shortterm and long-term periods. The combination of quantitative research with qualitative methods of expertise and content analysis of strategic documents for the regional development and innovative projects allowed assessing staffing needs for high-tech and innovative companies up to 2030 and identifying a list of priority occupations and competencies.

Keywords: region, high-tech sector, innovative sector, promising labor market, diagnostics, human resources, staffing needs

\section{INTRODUCTION}

The complexity of the task of staffing new sectors of the economy (high-tech, innovative) is due to the need to identify the emerging needs in the professional staff, which currently do not have customers from business. The methods used today to calculate the demand for the economy in labor resources do not fully considerate the systemic changes in the strategic priorities for the development of the regions. However, it is the technological and innovative changes in the economy that are the cause of the emergence of new requirements for professional personnel and their competencies leading to the formation of new labor markets. As a result, the efficiency and quality of 
the forecast of the personnel requirements of the regional economy are reduced. As a consequence, despite the existence of a high demand in labor resources by the economy, territorial, sectoral and professional-skill imbalances in supply and demand that impedes building the intellectual potential of the region.

The purpose of the study is to substantiate the methodology for diagnosing promising labor markets for forecasting the staffing needs of the high-tech and innovative sectors of the region's economy. The reported study was funded by Krasnoyarsk Region Science and Technology Support Fund according to the research project: KF-597.

\section{METHODS AND DATA}

In this study, a promising labor market is understood, firstly, as a new labor market that has not existed before, based on the emergence of new types of professions for new commodity markets and spheres of activity. Secondly, the market that provides the economy with labor resources that exerts the greatest influence on priority areas of socio-economic, technological or innovative development of the region [1-3]. The need to identify promising labor markets is explained by the existence of a temporary lag between the time of emergence and the satisfaction of the personnel needs of the economy in accordance with the priority areas of development. The main difficulty of this problem is to determine the number and professional structure of the workforce, the need for which is not fully formed by the time of diagnosis.

To develop a rigorous methodology for diagnosing prospective labor markets in the regional economy, a system-structural approach is used to identify factors of influence and patterns of changes in the business needs for professional staff, analyze differences in changes in personnel requirements in the regional economy, in identifying the interrelationships between the quantitative parameters of personnel needs and the intensity of technological and innovative development in the sectors of the region's economy, in support of this s diagnostic perspective of labor markets in the sectors of the economy of the region.

The processes of technological modernization and introduction of advanced production technologies are considered as prerequisites for changing the structure of the personnel requirements of the economy, breakthrough (cog-, info-, nano-, bio-) and innovative technologies into the economy, as a result of which the demand for educational levels, professions and qualifications.

The dynamics and volumes of investment in fixed assets, the number and scale of investment projects implemented in the region, the changing priorities of socioeconomic, technological and innovative development are considered as indicators of processes.

Table 1 presents the factors influencing the process of developing the components of staffing needs of the economy considering the differentiation of changes in quantitative and qualitative characteristics of professional competences and qualifications of employees. This allowed providing different approaches to the assessment of the components of staffing needs and establishing the relationship with changes in the economy.

Different rate of socioeconomic, technological and innovative development of the economy by types of economic activity, leads to the simultaneous existence of sectors belonging to different technological levels (traditional, high-tech, innovative 
technologies). This leads to forming the whole spectrum of staffing needs characterized by a variety of constituent components: for replacement, additional for priorities of social and economic development, additional for technological development, additional for innovative development and the professional and qualification structure of workers in the regional economy.

Table 1 - Changes in the structure of staffing needs resulting from the impact of economic growth

\begin{tabular}{|c|c|}
\hline Factors of influence & Pattern of changes in staffing needs \\
\hline $\begin{array}{l}\text { Global challenges to socio-economic and } \\
\text { technological development }\end{array}$ & $\begin{array}{l}\text { Change in the quantitative and qualitative } \\
\text { characteristics of staffing needs through the } \\
\text { formation of priority and new competencies }\end{array}$ \\
\hline $\begin{array}{l}\text { Socio-economic: } \\
\text { SES programs, investment projects (IP), } \\
\text { significant for individual business entities }\end{array}$ & $\begin{array}{l}\text { The structure of the staffing requirement (by } \\
\text { economic activities, levels and areas of training) } \\
\text { remains unchanged and is established from a } \\
\text { retrospective period }\end{array}$ \\
\hline $\begin{array}{l}\text { Investment projects (including transfer of } \\
\text { technologies): } \\
\text { - large-scale IP, changing the structure of the } \\
\text { economy and employment in the } \\
\text { implementation of IP and related industries, } \\
\text { focused on the development of existing labor } \\
\text { markets through the formation of priority } \\
\text { competencies }\end{array}$ & $\begin{array}{l}\text { The structure of the staffing needs is quantitatively } \\
\text { redistributed (by types of economic activity, levels } \\
\text { and areas of training) and is specified in accordance } \\
\text { with the staffing of investment projects } \\
\end{array}$ \\
\hline $\begin{array}{l}\text { Innovative projects (including the creation of } \\
\text { mother technologies): } \\
\text { - IP creation, implementation and dissemination } \\
\text { of innovations in the economy, focused on the } \\
\text { formation of new labor markets due to the } \\
\text { emergence of needs for new professions, } \\
\text { specialties and qualifications }\end{array}$ & $\begin{array}{l}\text { The structure of the staffing requirement varies } \\
\text { quantitatively and qualitatively, is established on the } \\
\text { basis of expert assessments formed by participants of } \\
\text { regional and national technology platforms, } \\
\text { representatives of business, science and education }\end{array}$ \\
\hline
\end{tabular}

Traditional technologies sector comprises the types of economic activity for which the modernization processes are the weakest. It is characterized by a steady demand for traditional professions and qualifications within the existing levels of education (BE, APE) and training directions (EGS - enlarged groups of specialties). The formation of the components of staffing requirements in this sector of the economy takes place based on two groups of reasons:

- the need for an additional number of employees for various reasons (retirement, long absence in the workplace, dismissal, natural loss);

- the need for an additional number of employees to implement priority areas of social and economic development and fill new jobs as a result of the organization of a new or expanding existing production based on traditional technologies or technological modernization of existing production.

High-tech sector comprises economic activities, characterized by active processes of technological development. It is identified by the use of novel technologies that have technical and economic advantages in comparison with traditional analog technologies. Characterized by the expanding demand for traditional and new qualifications in the framework of existing training areas (ETA). Formation of the main component of the 
staffing in this sector of the economy is conditioned by the need to employ an additional number of employees to fill high-tech jobs created in accordance with the priorities of technological development in the region.

Innovations sector includes economic activities with active introduction of innovative technologies, characterized by novelty and uniqueness, which do not have analog technologies. The peculiarity of the formation of the need for intellectual and personnel support of promising commodity markets and labor markets is the absence of business customers from the time of forecasting. In the long run, a qualitative change in demand for professional personnel and the formation of new labor markets are gradually taking place [4]. Formation of the key component of staffing needs in this sector is related to the need to employ an additional number of employees to fill the vacancies opening at innovative enterprises and organizations of the region. The structure of the components of the staffing needs of business in the regional economy is presented in Table 2.

Table 2 - Composition of components of staffing need for business in the sectors of the regional economy [5]

\begin{tabular}{|c|c|c|c|}
\hline \multirow[b]{2}{*}{$\begin{array}{l}\text { Sectors of the } \\
\text { regional economy }\end{array}$} & \multicolumn{3}{|c|}{ Components of staffing needs } \\
\hline & $\begin{array}{l}\text { For replacement; } \\
\text { additional for } \\
\text { priorities in the } \\
\text { social economic } \\
\text { development }\end{array}$ & $\begin{array}{l}\text { Additional for } \\
\text { technological } \\
\text { development }\end{array}$ & $\begin{array}{l}\text { Additional for } \\
\text { innovative development }\end{array}$ \\
\hline $\begin{array}{l}\text { Traditional } \\
\text { technologies }\end{array}$ & $\begin{array}{l}\text { Constant: } \\
\text { needs based on th } \\
\text { structure on EGS; } \\
\text { staffing needs fo } \\
\text { foreign trad } \\
\text { activities }\end{array}$ & No component & No component \\
\hline High-tech & $\begin{array}{l}\text { Constant } \\
\text { needs based on th } \\
\text { structure on publi } \\
\text { property developmen } \\
\text {; } \\
\text { staffing needs fo } \\
\text { foreign } \\
\text { activities }\end{array}$ & $\begin{array}{l}\text { In the short and medium } \\
\text { term: } \\
\text { component } \\
\text { quantitatively } \\
\text { redistributed by EGS; } \\
\text { foreign trade activities are } \\
\text { changed in accordance }\end{array}$ & No component \\
\hline Innovative & $\begin{array}{l}\text { Constant: } \\
\text { needs based on th } \\
\text { structure on publi } \\
\text { property } \\
\text { development; staffin } \\
\text { requirements } \\
\text { foreign fo } \\
\text { activities }\end{array}$ & $\begin{array}{l}\text { with the staffing of the IP; } \\
\text { In the long term: } \\
\text { the structure and } \\
\text { quantitative } \\
\text { characteristics of the } \\
\text { needs are determined on } \\
\text { the basis of an } \\
\text { independent assessment } \\
\text { of competencies (based } \\
\text { on the results of the } \\
\text { examination) }\end{array}$ & $\begin{array}{l}\text { In the long term: } \\
- \text { the structure and } \\
\text { quantitative } \\
\text { characteristics of the } \\
\text { needs are based on the } \\
\text { independent } \\
\text { estimation of new } \\
\text { qualifications } \\
\text { (occupations) based } \\
\text { on the results of the } \\
\text { examination }\end{array}$ \\
\hline
\end{tabular}

The division of the regional economy into sectors that create labor markets with the same set of components and a similar pattern of structural changes allows applying general rules in determining the professional composition of the forecasted components of the staffing needs within a sector and provide the basis for applying unified 
procedures for forecasting the vocational structure of staffing needs in the sectors of the regional economy. For example, in the traditional technologies sector, the quantitative and qualitative characteristics of staffing needs in the short-term are established from a retrospective considering the perspective growth rates of the economic branches while maintaining the demand structure (by economic activities, levels and areas of training). The situation is different in the high-tech and innovative sectors. The structure of the staffing needs of the high-tech sector in the medium-term period is quantitatively redistributed by types of economic activity, levels and areas of training and is specified in accordance with the staffing of investment projects. The structure of staffing needs in the innovation sector in the long-term varies quantitatively and qualitatively, and is established on the basis of expert assessments made by participants of regional and national technology platforms, representatives of business, science and education.

In order to identify promising labor markets, a methodology based on a combination of quantitative and qualitative approaches in solving this problem is proposed. On the basis of quantitative parameters of scenarios for technological, innovative and socioeconomic development of the region, the industries where staffing needs will be reoriented on labor resources for technological and innovative development are singled out, which will justify the need for the formation of promising labor markets in the region. The application of the examination methods can be helpful for establishing the qualitative composition of labor resources in these economic activities and setting the benchmarks for promising and new professional competencies. Stages of the proposed methodology are as follows.

Stage 1. Categorizing the sectors of the regional economy. The aim is to identify sectors of the economy with staffing needs reoriented on labor resources for technological and innovative development. To perform this task, an algorithm has been developed to divide the entire set of economic activities in accordance with the intensity of the building of high-tech and innovative industries. This algorithm includes three successive stages: calculation of the criteria for segmentation; identification of group differences in their values based on root-mean-square deviation; determination of the composition of segments. As a result, economic sectors (according to foreign trade activities) with different composition of requirements to labor resources are considering categorized against different requirements to the size and structure of professional staff.

The following indexes are proposed as criteria for segmentation:

Index of prospects of foreign economic activity $\left(I_{i}^{p r s}\right)$, which characterizes the intensity of processes of technological development in all foreign economic activities of the regional economy:

$$
I_{i}^{p r s}=\alpha_{1} \cdot d_{i}^{l b p}+\alpha_{2} \cdot d_{i}^{t p s}+\alpha_{3} \cdot d_{i}^{i r d},
$$

where $\alpha_{1}, \alpha_{2}, \alpha_{3}$ are the weights of each parameter included in the index "the prospects of foreign economic activity"; $d_{i}^{l b p}$ is rate of labor productivity growth in the $\mathrm{i}^{\text {th }}$ foreign trade activity (labor productivity); $d_{i}^{\text {tps }}$ is rate of growth of turnover of high-tech products of $i^{\text {th }}$ foreign trade activity (turnover of products and services); $d_{i}^{\text {ird }}$ is the growth rate of investment in research and development for the $i^{\text {th }}$ foreign trade activity (investment in research and development).

The innovation index of foreign economic activity $\left(I_{i}^{i n n}\right)$, reflecting the intensity of innovative development in the economy of the region: 


$$
I_{i}^{i n n}=\beta_{1} \cdot d_{i}^{\text {edi }}+\beta_{2} \cdot d_{i}^{\text {tip }}+\beta_{3} \cdot d_{i}^{i i n},
$$

where $\beta_{1}, \beta_{2}, \beta_{3}$ are weight coefficients of each parameter included in the index "innovation of foreign economic activity"; $d_{i}^{\text {edi }}$ is the growth rate of the number of employed in the development and implementation of innovations in the $\mathrm{i}^{\text {th }}$ foreign economic activity (employees in the development of innovations); $d_{i}^{\text {tip }}$ is the growth rate of the turnover of innovative products and services of $i^{\text {th }}$ foreign trade (turnover of innovative products); $d^{i i n}{ }_{i}$ is the growth rate of investment in innovation for the $i^{\text {th }}$ foreign trade activity in the foreign economic activity (investment in innovation).

2 Stage. Identifying emergence of promising labor markets in high-tech and innovative sectors of the region's economy considering the spatial distribution of economic resources. The aim is to assess the potential for the formation of local promising labor markets in the region, taking into account the geographic location and technological structure of geographic location. At this stage, the study moves to an intermediate level of the territorial structure of the economy - to associations of municipalities. This will partially eliminate the impact of sharp differentiation in the development of labor markets at the level of municipalities. As a result, after considering economic activities in general, the matrix structure of the regional economy is considered. The cells of the matrix include industries that form local labor markets in accordance with the economic sector they are a part of. According to the definition, prospective labor markets are positioned in the high-tech and innovative sectors of the region's economy. However, the potential for their formation in the region, first of all, is determined not by the technological structure and priorities of the development of industries, but by the strategies of individual enterprises, organizations and businesses located on the territory of specific municipalities.

We believe that identifying the emergence of promising labor markets in high-tech and innovative sectors of the region's economy are based on the correlation of the following indicators:

- specific weight $\left(\mathrm{d}_{\mathrm{ij}}\right)$ of a group of municipal entities (i) in the volume of production by type of economic activity (j) in the region;

- specific weight $\left(\mathrm{k}_{\mathrm{ij}}\right)$ of a group of municipal entities (i) in the number of persons engaged in economic activities (j) in the region.

Calculation of the indices $\mathrm{d}_{\mathrm{ij}}$ and $\mathrm{k}_{\mathrm{ij}}$ is carried out in accordance with the formulas:

$$
d_{i j}=\frac{Q_{i j}}{Q_{j}} ; \quad Q_{j}=\sum_{i=1}^{5} Q_{i j} ; \quad 1=\sum_{i=1}^{5} d_{i j} ; k_{i j}=\frac{N^{2} e_{i j}}{N e e_{j}} ; \quad N e e_{j}=\sum_{i=1}^{5} N e e_{i j} ; \quad 1=\sum_{i=1}^{5} k_{i j}
$$

where $Q_{j}$ is the volume of production by type of economic activity (j) in the region; $Q_{i j}$ is the volume of output produced by type of economic activity (j) created in a group of municipal entities (i); $\mathrm{Nee}_{\mathrm{j}}$ is the number of persons engaged in the production of goods and services by type of economic activity (j) in the region; $\mathrm{Nee}_{\mathrm{ij}}$ is the number of persons in a group of municipal entities (i) engaged in the production of goods and services by type of economic activity (j) in the region.

The ratio of indicators $\mathrm{d}_{\mathrm{ij}}$ and $\mathrm{k}_{\mathrm{ij}}$ can be used to identify promising labor markets in hightech and innovative sectors of the economy in accordance with the following conditions [6]: 
1) If the index of A. Salay $I_{s j}=\sqrt{\frac{1}{n} \cdot \sum_{i=1}^{n}\left(\left(d_{i j}-k_{i j}\right) /\left(d_{i j}+k_{i j}\right)\right)^{2}}>0.1-$ this indicates

the existence of strong differences between the structures of employment and the volumes of production by groups of municipalities for the type of economic activity (j). This fact allows us to formulate a hypothesis about the high differentiation of labor productivity at enterprises and organizations of this type of activity (j), located in different groups of municipalities. The reason is different levels of technologies used, which determine different requirements for vocational training of labor resources. The forecast values of the index will allow allocating groups of municipalities in which there is a high probability of the emergence of promising labor markets in advance.

2) If the ratio $d_{i j} \div k_{i j} \geq 1$ in a group of municipalities (i) confirms the hypothesis of applying technologies that have novelty and technical and economic advantages in comparison with analogical technologies traditionally used for the type of economic activity (j). In this case, the calculation of this ratio for the forecast indicators will make it possible to assert that in the group of municipalities (i) there is a high probability of the emergence of promising labor markets.

3 Stage. Identifying the parameters of the prospective labor markets. The aim is to determine quantitative and qualitative parameters of prospective labor markets taking into account the required professional competencies and the assessment of new qualifications (occupations) in groups of municipalities. The main research methods at this stage are the content analysis of strategies, programs and projects of socioeconomic, technological and innovative development of the region, interviews with employers and expert sessions with representatives of science, education and business. In the course of research on each promising labor market (the result of stage 2 of this methodology), experts form groups of "tasks for the future"; identify promising competencies, the development of which is based on existing educational programs; Determine the need for new competencies and new professions [7-12].

\section{RESULTS}

The case for the Krasnoyarsk Krai presents the algorithm of how promising labor markets were identified considering the target parameters of socio-economic, technological and innovative development until 2030 [13;14].

1) The sectoral composition of the regional economic sectors is established (Table 3).

Table 3 - Composition of economic sectors of the Krasnoyarsk Krai in 2017

\begin{tabular}{|l|l|c|}
\hline Sector of economy & $\begin{array}{l}\text { Types and subtypes of economic activity (in } \\
\text { accordance with the All-Russian Classifier of } \\
\text { Economic Activities [15]) }\end{array}$ & $\begin{array}{c}\text { Total } \\
\text { foreign } \\
\text { trade } \\
\text { activities }\end{array}$ \\
\hline Traditional technologies & $\begin{array}{l}\text { B, DA, DB, DC, DD, DE, DF, DG, DH, DI, } \\
\text { DK, DL, DM, DN, H, J, L, N, O }\end{array}$ & 19 \\
\hline High-tech & C, DJ, E, K & 4 \\
\hline Innovative & A, F, G, I, M & 5 \\
\hline
\end{tabular}

2) The scenarios for the economic sectors development of up to 2020 have been determined: 
For the Traditional technologies sector the annual growth rate makes $101.3 \%$; the average growth rate of investments in fixed assets by foreign economic activity is $101.9 \%$; the average growth rate of social labor productivity is $101.4 \%$.

For the High-tech and Innovative sectors the average annual growth rate is $106.3 \%$; the average growth rate of investments in fixed assets by foreign economic activity is $104.9 \%$; the average growth rate of social labor productivity is $102.9 \%$.

3) The list of priority occupations for the regional economy is indicated.

Table 4 - The list of priority occupations in the sectors of the economy of the Krasnoyarsk Krai (fragment) [9-10]

\begin{tabular}{|c|c|c|}
\hline $\begin{array}{l}\text { Segments of regional } \\
\text { economy sectors }\end{array}$ & Before 2020 & After 2020 \\
\hline $\begin{array}{l}\text { High-tech } \\
\text { Extraction and processing } \\
\text { of minerals (the All- } \\
\text { Russian classifier of kinds } \\
\text { of economic activity "C") }\end{array}$ & $\begin{array}{l}\ldots \\
\text { System mine Engineer } \\
\text { Eco-analyst in extractive } \\
\text { industries } \\
\text { Engineer of robotic systems }\end{array}$ & - \\
\hline $\begin{array}{l}\text { High-tech } \\
\text { Production and distribution } \\
\text { of electricity, gas and water } \\
\text { (the All-Russian classifier } \\
\text { of kinds of economic } \\
\text { activity "E") }\end{array}$ & $\begin{array}{l}\text { The attendant / controller of } \\
\text { power networks for distributed } \\
\text { energy } \\
\text {... }\end{array}$ & $\begin{array}{l}\text { Power consumption } \\
\text { network developer } \\
\text { System engineer of } \\
\text { intelligent power } \\
\text { networks } \\
\ldots\end{array}$ \\
\hline $\begin{array}{l}\text { Innovative } \\
\text { New materials and } \\
\text { nanotechnology }\end{array}$ & $\begin{array}{l}\text { Glazier (specialist in the } \\
\text { development and production of } \\
\text { glass products based on glass } \\
\text { composite materials) } \\
\text { System Engineer of Composite } \\
\text { Materials } \\
\ldots\end{array}$ & $\begin{array}{l}\text { The designer of the } \\
\text { "smart environment" } \\
\text { Specialist in } \\
\text { nanoindustry security } \\
\text {... }\end{array}$ \\
\hline
\end{tabular}

\section{CONCLUSION}

Using the methodology for identifying promising labor markets on the basis of a combination of quantitative and qualitative research methods (content analysis of strategic documents, programs and projects of socio-economic, technological and innovative development of the region, surveys of employers, expert sessions with representatives of science, education and business). Staffing of new sectors of the economy (high-tech sector, "knowledge economy") and record changes in the structure of territorial, sectoral, vocational-qualification in the sectors of the region's main specialization.

\section{REFERENCES}

[1] Gimpelson, V.E., Development of a methodology for forecasting long-term labor market needs in graduates of the vocational education system [Electronic resource]. Access mode: https://www.hse.ru/org/projects/25622. (in Russian)

[2] Vasilyeva, Z.A., Formation of the mechanisms of economic growth based on the concept of utility, 2005, 250 p. (in Russian) 
[3] Vasiliev, V.N., The labor market and the market of educational services in the subjects of the Russian Federation, 2007, 680 p. (in Russian)

[4] Gurtov,V.A., Knyazev, E.A., Pitukhin, E.A., Trends in the labor market in the context of the impact of the global crisis on the Russian economy and the role of the vocational education system in staffing the prospective labor markets in the post-crisis period, 2009, 107 p. (in Russian)

[5] Filimonenko, I.V., Typification of the economy of the region for forecasting the personnel requirement, Economic and social changes: facts, trends, forecast, № 4 (28), 2013, pp. 121-132. (in Russian)

[6] Elkhina, I.A., Structural shifts and structural differences of economic systems in Russia, Bulletin of the Saratov State Social and Economic University, 4 (53), 2014, pp. 38-41. (in Russian)

[7] Shabaeva, S.V., Fedorova, S.A., Stepus, I.S., Demanded professions in the Arctic zone of Russia as a reflection of the priorities for the development of the macro-region's economy, Problems of Management, 7, 2016, pp. 104-117. (in Russian)

[8] On the approval of the list of the 50 most demanded in the labor market, new and promising occupations that require secondary vocational education. Order of the Ministry of Labor of Russia № 831 of November 2, 2015. Access mode: http://www.rosmintrud.ru/docs/mintrud/orders/436. (in Russian)

[9] Sudakov, D.A., Atlas of new professions: instructions for use, Intellect of the Future, 2016, 40 p. (in Russian)

[10] Atlas of new professions, ANO ASI, Skolkovo, 2015, 288 p. (in Russian)

[11] Atlas of new professions, ANO ASI, Skolkovo, 2014, 168 p.(in Russian)

[12] The base center "Worldskills Russia" [Electronic resource]. Access mode: http://worldskills.ru/techcom/kompetencii/. (in Russian)

[13] Strategy of social and economic development of the Krasnoyarsk Krai until 2030 (project) [Electronic resource]. Access mode: http://www.krskstate.ru/2030. (in Russian)

[14] The concept of industrial policy of the Krasnoyarsk Krai until 2030 from 15.12.2015 [Electronic resource]. Access mode: http://www.krskstate.ru/promtorg/strateg. (in Russian)

[15] All-Russian classifier of economic activities [Electronic resource]. Access mode: http://www.buxprofi.ru/spravochnik/okved-2. (in Russian) 